\title{
Differential effect of corn oil-based low trans structured fat on the plasma and hepatic lipid profile in an atherogenic mouse model: comparison to hydrogenated trans fat
}

\author{
Yun-Young Cho ${ }^{1,2}$, Eun-Young Kwon ${ }^{1,2}$, Hye-Jin Kim ${ }^{4}$, Seon-Min Jeon ${ }^{1,2}$, Ki-Teak Lee ${ }^{3}$, Myung-Sook Choi ${ }^{1,2^{*}}$
}

\begin{abstract}
Background: Trans fat are not desirable in many aspects on health maintenance. Low trans structured fats have been reported to be relatively more safe than trans fats.

Methods: We examined the effects of low trans structured fat from corn oil (LC), compared with high trans fat shortening, on cholesterol and fatty acid metabolism in apo E deficient mice which is an atherogenic animal model. The animals were fed a high trans fat (10\% fat: commercial shortening (CS)) or a low trans fat (LC) diet for 12 weeks.

Results: LC decreased apo B and hepatic cholesterol and triglyceride concentration compared to the CS group but significantly increased plasma total cholesterol and triglyceride concentration and fecal lipids with a simultaneous increase in HDL-cholesterol level, apo A-I, and the ratio of HDL-cholesterol to total cholesterol (HTR). Reduction of hepatic lipid levels by inclusion of LC intake was observed alongside modulation of hepatic enzyme activities related to cholesterol esterification, fatty acid metabolism and fecal lipids level compared to the CS group. The differential effects of LC intake on the plasma and hepatic lipid profile seemed to be partly due to the fatty acid composition of LC which contains higher MUFA, PUFA and SFA content as well as lower content of trans fatty acids compared to CS.

Conclusions: We suggest that LC may exert a dual effect on plasma and hepatic lipid metabolism in an atherogenic animal model. Accordingly, LC, supplemented at 10\% in diet, had an anti-atherogenic effect on these apo $E^{-\gamma}$ mice, and increased fecal lipids, decreased hepatic steatosis, but elevated plasma lipids. Further studies are needed to verify the exact mode of action regarding the complex physiological changes and alteration in lipid metabolism caused by LC.
\end{abstract}

\section{Introduction}

Fat in foods has great palatability and can be addictive to animals [1,2] and human beings [3]. Fats and oils as they exist in nature must be processed before they are suitable for human consumption [4]. Partial hydrogenation of vegetable oils is a common technological aid to food processing with few or no undesirable effects although it can alter the composition of fatty acids.

\footnotetext{
* Correspondence: mschoi@knu.ac.kr

'Department of Food Science and Nutrition, Kyungpook National University, Daegu, South Korea

Full list of author information is available at the end of the article
}

Types of polyunsaturated fatty acids (PUFA) in dietary fats have been shown to profoundly influence lipid metabolism and physiological function. In particular, linoleic acid (18:2, n-6, LA) and $\alpha$-linolenic acid (18:3, n-3) are metabolized to highly unsaturated fatty acids which have distinct physiological functions [5]. However, epidemiological evidence suggests a strong relationship between the intake of trans fatty acids, which are formed during the hydrogenation process, and the risk of coronary heart disease (CHD) [6-8]. The effect of trans fatty acids on the serum lipoprotein profile is at least as unfavorable as that of cholesterol-raising
Ciomed Central

() 2011 Cho et al; licensee BioMed Central Ltd. This is an Open Access article distributed under the terms of the Creative Commons Attribution License (http://creativecommons.org/licenses/by/2.0), which permits unrestricted use, distribution, and reproduction in any medium, provided the original work is properly cited. 
saturated fatty acids, because trans fatty acids not only raise low-density lipoprotein (LDL) cholesterol levels but also lower high-density lipoprotein (HDL) cholesterol levels. Later studies, involving either partially hydrogenated fat as the source of trans fatty acids or specifically synthesized fat differing in only a single fatty acid, further demonstrate the blood cholesterol raising effects of trans fatty acids [9-12].

In this study, we attempted to synthesize a novel structured lipid using corn oil. LA is the primary (in terms of mass consumed) essential fatty acid in corn oil. It can reduce plasma total cholesterol and LDL-cholesterol $[13,14]$, each of which is an established CHD risk factor. In the present study, the novel structured lipid was produced from corn oil by lipase-catalyzed glycerolysis, which produced a lipid rich in monounsaturated fatty acid (MUFA) and PUFA compared to trans fats. This novel structured lipid may provide a beneficial effect on lipid metabolism. Accordingly, we examined the physiological effects of our novel structured lipid on the plasma and hepatic lipid profile in apo $E^{-/-}$mice, an animal model of atherosclerosis.

\section{Materials and methods Test Oil}

A commercial shortening (CS, New Orleans, USA) and a low trans structured fat from corn oil (LC, Seoul, Korea) were used in this study. $500 \mathrm{~g}$ oil blends of anhydrous butterfat (ABF), palm stearin (PS) and corn oil (CO) $(8 / 6 / 6$ and $6 / 6 / 9, \mathrm{w} / \mathrm{w} / \mathrm{w})$ were added respectively into a 1-L tank stirred-batch type reactor. The tank height and diameter was $11 \mathrm{~cm}$ and $15 \mathrm{~cm}$ respectively. The enzyme load was $10 \%$ of total substrates $(50 \mathrm{~g}$, w/ w). The reaction was stirred at $230 \mathrm{rpm}$ by an impeller (blade length: $9 \mathrm{~cm}$; blade width: $3.3 \mathrm{~cm}$ ) and stirrer motor (M Tops MS-3060D, Korea). Lipozyme RM IM and Novozyme 435 were used for blending mixture of $8 / 6 / 6$ and $6 / 6 / 9$ by mass (ABF/PS/CO). The reaction for production of the modified-butterfat was carried out for $24 \mathrm{hr}$ in a solvent-free system. Samples were withdrawn during the reaction according to the time course, and then filtered by PTFE syringe membrane filter $(25 \mathrm{~mm}$, $0.2 \mu \mathrm{m}$, Whatman, USA) to remove the enzyme for analysis. The fatty acid profile was analyzed for each fat used (Table 1).

\section{Animals and Diets}

Twenty male apolipoprotein E-deficient (apo $E^{-/}$) mice, a well established animal model of atherosclerosis, were imported from Jackson Laboratory (Bar Harbor, Maine, USA) at 5 weeks of age. All the mice were individually housed under a constant temperature $\left(24^{\circ} \mathrm{C}\right)$ with $12 \mathrm{~h}$ light $/ 12 \mathrm{~h}$ dark cycle and fed a palletized commercial chow diet for 1 week after arrival. The mice were then
Table 1 Fatty acid composition of two dietary lipids, a hydrogenated trans fat and a corn-oil based low trans structured fat, used in animal experiment

\begin{tabular}{|c|c|c|}
\hline & \multicolumn{2}{|r|}{ (unit : \%) } \\
\hline & CS & LC \\
\hline $14: 00$ & 0.11 & 0.71 \\
\hline $16: 00$ & 13.42 & 35.81 \\
\hline $16: 01$ & 0.07 & 0.07 \\
\hline $18: 00$ & 11.56 & 15.65 \\
\hline 18:01 & 12.64 & 24.07 \\
\hline 18:02 & 5.39 & 22.72 \\
\hline $18: 03$ & 0.22 & 0.55 \\
\hline $20: 00$ & 0.06 & - \\
\hline 20:01 & 0.25 & - \\
\hline $18: 1 T$ & 43.84 & - \\
\hline $18: 2 T$ & 11.91 & - \\
\hline $18: 3 T$ & 0.50 & 0.42 \\
\hline Total Trans & 56.25 & 0.42 \\
\hline$n-6$ & 5.39 & 22.72 \\
\hline$n-3$ & 0.22 & 0.55 \\
\hline n-6/n-3 ratio & 24.50 & 41.31 \\
\hline SFA & 25.15 & 52.17 \\
\hline MUFA & 12.71 & 24.14 \\
\hline PUFA & 5.61 & 23.27 \\
\hline $\mathrm{P} / \mathrm{S}$ & 0.22 & 0.45 \\
\hline
\end{tabular}

SFA, saturated fatty acid; MUFA, monounsaturated fatty acid; PUFA, polyunsaturated fatty acid; P/S, PUFA/SFA ratio.

CS, commercial shortening; LC, low trans structured fat from corn oil.

randomly divided into two groups $(\mathrm{n}=10)$ and fed the AIN-76 (American Institute of Nutrition, 1977) basal diet containing 10\% (wt/wt) test oil for 12 weeks (Table 2).

Free access was given to food and water. Blood was taken from a tail vein for the determination of plasma total cholesterol and triglyceride concentration at 0 , 3rd, 6th, 9th and 12th wks. Every day for the last 4 days, the

Table 2 Composition of experimental diets composed of a hydrogenated trans fat and a corn-oil based low trans structured fat (unit : \% of diet)

\begin{tabular}{lcc}
\hline Groups Ingredients & CS & LC \\
\hline Casein & 20 & 20 \\
Methionine & 0.3 & 0.3 \\
Sucrose & 50 & 50 \\
Cone starch & 10 & 10 \\
Fiber & 5 & 5 \\
Test oils & 10 & 10 \\
Cholinebitartrate & 0.2 & 0.2 \\
Mineral mixture & & 3.5 \\
Vitamin mixture $^{\mathrm{b}}$ & 3.5 & 1 \\
\hline Total & 1 & 100 \\
\hline
\end{tabular}

${ }^{\mathrm{a}}$ AIN-76 mineral mixture (Harlan Teklad Co., Madison, WI).

${ }^{\mathrm{b}} \mathrm{AIN}-76$ vitamin mixture (Harlan Teklad Co.).

CS, commercial shortening; LC, low trans structured fat from corn oil. 
feces were collected and analyzed for fecal lipids. The food consumption and body weight were measured daily and weekly. At the end of the experimental period, the mice were anesthetized with ketamine- $\mathrm{HCl}$ after food was withheld for 14 hours. Blood samples were taken from the inferior vena cava for plasma lipid analysis. The organs and adipose tissues were removed and rinsed with physiological saline. All samples were stored at $-70^{\circ} \mathrm{C}$ until analysis. This experimental design was approved by the Ethics Committee of Kyungpook National University for the care and use of laboratory animals.

\section{Plasma, hepatic and fecal lipid analysis}

The plasma triglyceride, total cholesterol and HDL-cholesterol concentrations were enzymatically determined using a commercial kit (Sigma). The plasma apolipoprotein A-I (apo A-I), apolipoprotein B (apo B) and nonesterified fatty acid (NEFA) were also measured using commercial assay kits (Nitto Boseki Co. Ltd, Japan, NEFA-Wako Pure Chemical Industries). The hepatic lipids were extracted using the procedure developed by Folch et al. [15]. The dried lipid residues were dissolved in $1 \mathrm{ml}$ of ethanol for cholesterol and triglyceride assays. Triton X-100 and a sodium cholate solution (in distilled $\mathrm{H}_{2} \mathrm{O}$ ) were added to $200 \mu \mathrm{L}$ of the dissolved lipid solution to produce final concentrations of $5 \mathrm{~g} / \mathrm{L}$ and $3 \mathrm{mmol} / \mathrm{L}$, respectively. The hepatic cholesterol and triglycerides were analyzed with the same enzymatic kit as used in the plasma analysis.

The feces from each group were collected daily for 1 week and analyzed for lipids, as described previously with a slight modification [15]. Briefly, the feces were dried and extracted in ice-cold chloroform and methanol $(2: 1, \mathrm{v} / \mathrm{v})$ for $24 \mathrm{~h}$ at $4^{\circ} \mathrm{C}$. After centrifugation at $900 \times g$ for $10 \mathrm{~min}$, the supernatant was collected, dried at $50^{\circ} \mathrm{C}$, and dissolved with ethanol. The fecal cholesterol and triglyceride levels were estimated using the same method as used for the liver.

\section{Preparation of hepatic tissue enzyme source}

Enzyme source fractions from hepatic tissue were prepared as follows. The tissue $0.5 \mathrm{~g}$ was homogenized in a fivefold volume of $0.25 \mathrm{M}$ sucrose buffer and centrifuged at $600 \times \mathrm{g}$ for $10 \mathrm{~min}$ to remove any cell debris and then the supernatant was centrifuged at $10,000 \times$ g for $20 \mathrm{~min}$ to isolate the mitochondrial pellet. Finally, the supernatant was further ultracentrifuged at $105,000 \times \mathrm{g}$ for 60 min to obtain the cytosol supernatant. Protein contents in the mitochondrial and cytosolic fractions were measured according to the method of Bradford [16] using bovine serum albumin as the standard.

\section{Hepatic lipid regulating enzyme activities}

Glucose-6-phosphate dehydrogenase (G6PD) activity was assayed by spectrophotometric methods according to the procedures described by Pitkanen et al. [17], where the activity was expressed as the reduced $\mathrm{NADPH}$ (nmol/min/mg protein). The supernatant cytosolic fractions were analyzed for malic enzyme (ME) (EC 1.1.1.40) using modification of the methods of Ochoa [18]. ME activity was expressed as nmol NADPH ( $\mathrm{nmol} / \mathrm{min} / \mathrm{mg}$ protein). The hepatic $\beta$-oxidation was measured spectrophtometrically by monitoring the reduction of NAD to NADH in the presence of palmitoyl-CoA [19]. The reaction was initiated by addition of the enzyme source to a reaction cuvette containing 20 mM NAD, $0.33 \mathrm{M}$ dithiothreitol, 1.5\% bovine serum albumin, 2\% Triton X-100, $10 \mathrm{mM}$ CoA, $1 \mathrm{mM}$ FAD, $100 \mathrm{mM} \mathrm{KCN}$, and $5 \mathrm{mM}$ palmitoyl-CoA in $50 \mathrm{mM}$ Tris- $\mathrm{HCl}(\mathrm{pH} 8.0)$. The reaction compartment was thermostatted at $37^{\circ} \mathrm{C}$, and the reaction rate was followed at $340 \mathrm{~nm}$. Data were expressed as nmol of NAD reduced/ $\mathrm{min} / \mathrm{mg}$ of protein. The carnitine palmitoyl transferase (CPT) activity was determined according to the method of Markwell et al. [20]. The results were expressed as $\mathrm{nmol} / \mathrm{min} / \mathrm{mg}$ protein.

\section{3-Hydroxy-3-methylglutaryl (HMG)-CoA reductase and acyl-CoA:cholesterol acyltransferase (ACAT) activities}

The HMG-CoA reductase activity in the microsomal fraction was measured with $\left[{ }^{14} \mathrm{C}\right] \mathrm{HMG}-\mathrm{CoA}$ as the substrate based on a modified method of Shapiro [21], where the activity was expressed as the synthesized mevalonate ( $\mathrm{pmol} / \mathrm{min} / \mathrm{mg}$ protein). The ACAT activity in the microsomes was determined by the rate of incorporation of $\left[{ }^{14} \mathrm{C}\right]$ oleoyl-CoA into the cholesterol ester fraction, as described by Erickson [22], where the activity was expressed as synthesized cholesteryl oleate (pmol/min/mg protein).

\section{Hepatic Tissue Morphology}

Livers were removed and fixed in a buffer solution of $10 \%$ formaldehyde. Fixed tissues were processed routinely for paraffin embedding, and 4- $\mu \mathrm{m}$ sections were prepared and dyed with hematoxylin-eosin. Stained areas were viewed using an optical microscope $\times 100$ magnification.

\section{Statistical analysis}

All data are presented as the mean \pm S.E. Statistically significant differences between the groups were determined with a Student's $t$ test $(p<.05)$ using the standard social science statistical package (SPSS, Chicago, IL, USA). 
Table 3 Effect of supplementation of a hydrogenated trans fat and a corn-oil based low trans structured fat on food intake, weight gain, food efficiency ratio (FER) and organ weights in apo $E^{/-}$mice

\begin{tabular}{lcc}
\hline Group & CS & LC \\
\hline Food Intake (g/day) & $4.32 \pm 0.09$ & $4.35 \pm 0.11$ \\
Weight gain (g/day) & $0.12 \pm 0.01$ & $0.15 \pm 0.01^{* *}$ \\
FER & $0.03 \pm 0.00$ & $0.03 \pm 0.00^{*}$ \\
\hline Organ Weights (g/100 g B.W.) & & \\
Liver & $6.78 \pm 0.29$ & $5.21 \pm 0.08^{* * *}$ \\
Heart & $0.46 \pm 0.01$ & $0.37 \pm 0.02^{* *}$ \\
\hline
\end{tabular}

Data are mean \pm S.E. $(n=10)$.

Values are significantly different from the CS group according to Student's $t$ test: ${ }^{*} P<.05,{ }^{* *} P<.01,{ }^{* * *} P<.001$

FER : Food efficiency ratio $=$ body weight gain/food intake; B.W., Body Weight CS, commercial shortening; LC, low trans structured fat from corn oil

\section{Results}

Food intake, weight gain, FER and organ weights

Weight gain and food efficiency ratio (FER) were significantly higher in the LC group compared to the CS group, with no change in food intake. The weight of liver and heart (g/100 g body weight) was significantly lower in the LC group than in the CS group (Table 3).

Plasma, hepatic and fecal lipids

The plasma total cholesterol and triglyceride levels were significantly higher in the LC group (Table 4). While free fatty acid concentration was unchanged. The HDL-

Table 4 Effect of supplementation of a hydrogenated trans fat and a corn-oil based low trans structured fat on plasma, hepatic and fecal lipid levels in apo $E^{-/-}$mice

\begin{tabular}{lcc}
\hline & CS & LC \\
\hline Plasma lipids & & \\
Free fatty acid (mmol/L) & $1.14 \pm 0.03$ & $1.11 \pm 0.04$ \\
Triglyceride (mmol/L) & $1.46 \pm 0.09$ & $2.09 \pm 0.08^{* * *}$ \\
Total-C (mmol/L) & $16.45 \pm 0.81$ & $18.75 \pm 0.37^{*}$ \\
HDL-C (mmol/L) & $0.11 \pm 0.02$ & $0.81 \pm 0.06^{* * *}$ \\
HDL-C/Total-C (\%) & $0.60 \pm 0.06$ & $4.06 \pm 0.39^{* * *}$ \\
Atherogenic index & $174.95 \pm 18.05$ & $23.39 \pm 1.99^{* * *}$ \\
Apo A-I (mg/dL) & $4.46 \pm 0.57$ & $7.47 \pm 0.25^{* * *}$ \\
Apo B (mg/dL) & $21.00 \pm 0.54$ & $17.19 \pm 0.60^{* * *}$ \\
Hepatic lipids & & \\
Cholesterol (mmol/g liver) & $7.88 \pm 0.03$ & $5.83 \pm 0.19^{* * *}$ \\
Triglyceride $(\mathrm{mmol} / \mathrm{g}$ liver) & $7.21 \pm 0.34$ & $5.27 \pm 0.18^{* *}$ \\
Fecal lipids & & \\
Cholesterol $(\mu \mathrm{mol} / \mathrm{g})$ & $4.60 \pm 0.28$ & $6.44 \pm 0.37^{* *}$ \\
Triglyceride $(\mu \mathrm{mol} / \mathrm{g})$ & $2.22 \pm 0.54$ & $4.44 \pm 0.85^{*}$ \\
\hline
\end{tabular}

Data are mean \pm S.E. $(n=10)$. Values are significantly different from the CS group according to Student's $t$ test: ${ }^{*} P<.05,{ }^{* *} P<.01$, ${ }^{* *} P<.001$. C: cholesterol.

${ }^{a}$ Atherogenic index: (Total-C-HDL-C)/HDL-C

CS, commercial shortening; LC, low trans structured fat from corn oil. cholesterol, apo A-I, fecal lipids concentrations and the ratio of HDL-cholesterol to total cholesterol were also significantly higher in the LC group compared to the CS group (Table 4). In addition, hepatic triglyceride, hepatic cholesterol, apo B concentration and atherogenic index, which are all significant risk factors of coronary heart disease, were significantly lower in the LC group (Table 4).

Enzyme activities related to fatty acid metabolism in liver The hepatic and adipocyte G6PD and ME activity were significantly lower in the LC group compared to the CS groups (Table 5 ). The activity of hepatic $\beta$-oxidation and CPT, the rate-limiting enzyme in fatty acid oxidation, was significantly higher in the LC group compared to the CS group (Table 5).

\section{Hepatic HMG-CoA reductase and ACAT activities}

The hepatic ACAT activity was significantly lower in the LC supplemented group than in the CS group, while the hepatic HMG-CoA reductase activity was not significantly between the groups (Figure 1).

\section{Morphological changes in hepatocytes}

Lipid droplet accumulation in liver was lower in the LC group compared to the CS group when observed in the light microscope (Figure 2). This result was consistent with the hepatic triglyceride and cholesterol profile shown in Table 4.

\section{Discussion}

The present study demonstrates the differential effect of two solid fats, a low trans structured fat and a hydrogenated trans fat, on plasma and hepatic lipid metabolism in apo $E^{-/-}$mice. Trans fatty acid intake has been convincingly shown to be associated with a significantly higher risk of heart disease based on large epidemiology

Table 5 Effect of supplementation of a hydrogenated trans fat and a corn-oil based low trans structured fat on the enzyme activities related to the hepatic fatty acid metabolism in apo $E^{-/-}$mice

\begin{tabular}{lcc}
\hline & CS & LC \\
\hline Fatty acid synthesis & & \\
G6PD (nmol/min/mg protein) & $24.90 \pm 2.74$ & $7.42 \pm 0.30^{* * *}$ \\
ME (nmol/min/mg protein) & $217.4 \pm$ & $126.58 \pm$ \\
& 18.64 & $15.32^{* *}$ \\
Fatty acid oxidation & & \\
$\quad \begin{array}{l}\beta \text {-oxidation }(\mu \mathrm{mol} / \mathrm{min} / \mathrm{mg} \\
\text { protein) }\end{array}$ & $0.43 \pm 0.08$ & $5.42 \pm 1.13^{*}$ \\
$\quad$ CPT (nmol/min/mg protein) & $19.86 \pm 1.42$ & $27.09 \pm 1.56^{* *}$ \\
\hline
\end{tabular}

Data are mean \pm S.E. $(n=10)$. Values are significantly different from the CS group according to Student's $t$ test: ${ }^{*} P<.05,{ }^{* *} P<.01$, ${ }^{* *} P<.001$. G6PD, glucose-6-phosphate dehydrogenase; ME, malic enzyme; CPT, carnitine palmitoyl transferase.

CS, commercial shortening; LC, low trans structured fat from corn oil. 


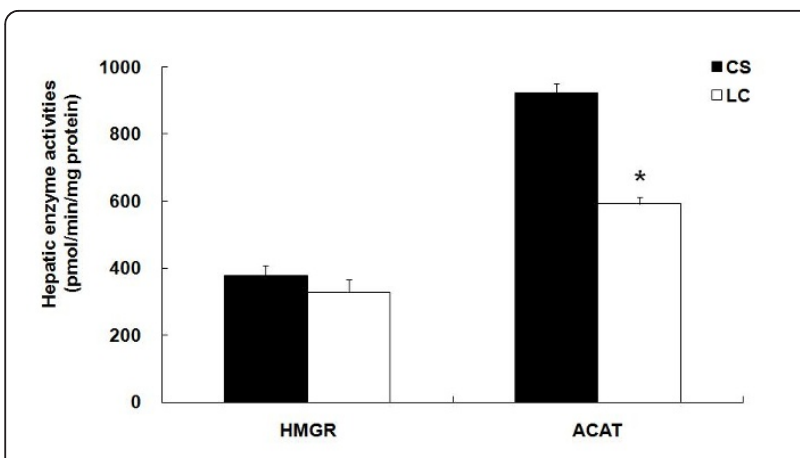

Figure 1 Effect of supplementation of a hydrogenated trans fat and a corn-oil based low trans structured fat on HMG-CoA reductase (HMGR) and ACAT activities in apo $E^{\prime-}$ mice : CS group ( $\square$ ) and LC group ( $\square$ ). The results represent mean \pm S.E. ( $n$ $=10$ ). Values are significantly different from the CS group according to Student's $t$ test: ${ }^{*} P<.05$. HMGR, 3-hydroxy-3-methylglutarylcoenzyme reductase; ACAT, acyl CoA: cholesterol acyltransferase. CS, commercial shortening; LC, low trans structured fat from corn oil.

and clinical studies [23-25]. Previously in a comprehensive review of past studies summarized trans fatty acid intake significantly effects blood lipids, in particular the LDL-cholesterol/HDL-cholesterol ratio and total cholesterol/HDL-cholesterol ratio, leading to increased risk of $\mathrm{CHD}$ risk [26]. In the present study, plasma HDLcholesterol, apo A-I concentrations and HTR were significantly increased, whereas apo B level were significantly lower in the LC group than in the CS group. Apo B and apo A-I are thought to be better predictors of CHD risk than total cholesterol and LDL-cholesterol [27]. Apo A-I also acts as a cofactor for lecithin: cholesterol acyltransferase (LCAT) [28], which is an important enzyme involved in removing excess cholesterol from tissues and incorporating it into HDL for reverse cholesterol transport to the liver [29]. Apo $B$ is synthesized in the liver and is present in LDL, IDL and VLDL particles [29], and therefore the total apo B concentration indicates the amount of potentially atherogenic lipoproteins in plasma or liver [30].

Previous studies have shown that eating partially hydrogenated lipids results in an increase in liver phospholipid concentrations [31]. In the present study, hepatic cholesterol, triglyceride and lipid droplet accumulation in liver was also significantly lowered in the LC group than in the CS group which may contribute reducing liver weight. Hence LC consumption appears to prevent the development of hepatic steatosis in apo E deficient mice. Elevated excretion of cholesterol and triglyceride was also observed in LC fed mice. However, plasma total-C and triglyceride concentration were significantly higher in the LC group than in the CS group. It is plausible that the difference in fatty acid composition between CS and LC could have led to the paradoxical finding of an antiarterogenic effect in liver but negative pro-arteriogenic effect in blood although at present the mechanism is unclear. A commercial low trans fat with high MUFA, myristic acid and palmitic acid content also exhibited the same hepatic lipid-lowering effect but paradosical increase in the plasma cholesterol concentration [32]. Current findings support the dual effects of low trans fats, in part, can be modulated by the fatty compositions of these structured fats. Saturated fatty acids (SFAs) are

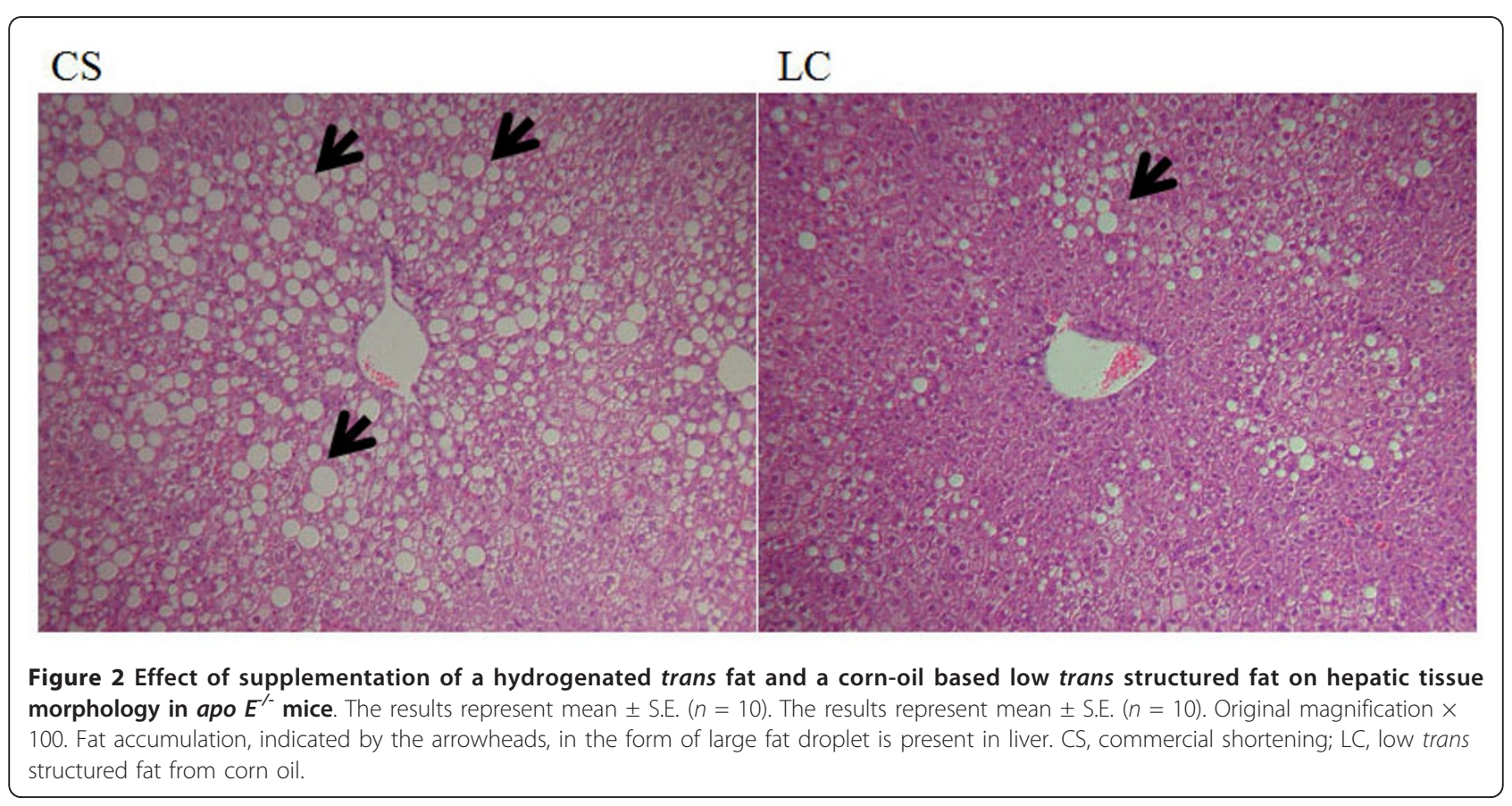


major dietary constituents that can raise plasma total-C concentration [33]. The cholesterol raising properties of SFAs can be primarily attributed to myristic acid (14:0) and palmitic acid (16:0). These SFAs may have different effects on serum total cholesterol concentrations [34]. Replacing SFA with MUFA reduces total cholesterol, LDL-cholesterol, and triglyceride concentrations [35]. Alternatively, the differential effects of low trans fat on lowering hepatic lipids in apo $E^{-/-}$mice can be attributed to their specific fatty acid composition. The CS contains more trans fatty acid and less SFA per se in comparison to LC which is rich in linoleic acid, however in MUFA and PUFA vice versa is true and the relative amount of SFA is higher.

Regarding cholesterol metabolism, dietary LC did not significantly lower hepatic HMG-CoA reductase activity, however LC significantly decreased hepatic ACAT activity. HMG-CoA reductase is the rate-limiting enzyme in the cholesterol biosynthetic pathway that converts HMG-CoA to mevalonate [36,37]. Intracellular cholesteryl ester (CE) synthesis catalyzed by ACAT serves to store cholesterol in cytosolic droplets and also participates in the hepatic secretion of lipoproteins containing apo B [38-40]. Moreover, ACAT is believed to be involved in cholesterol absorption from the intestine [41] although this was beyond the scope of the present study. Under pathological conditions, the chronic accumulation of CE produced by ACAT in macrophages and arterial smooth muscle cells leads to the characteristic foam cell formation in atherosclerosis [42]. Therefore, ACAT inhibitors are also expected to be cholesterollowering and hence potential anti-atherosclerotic agents.

In summary, an increased hepatic fatty acid synthesis was correlated with the availability of fatty acids for triglyceride synthesis [43]. The activities of two hepatic enzymes G6PD and ME, related to fatty acid synthesis, were lower in the $\mathrm{LC}$ supplemented apo $\mathrm{E}^{-/-}$mice in this study. Taken together these findings suggest that the LC supplement had a hepatic triglyceride-lowering effect via lowering the hepatic lipogenic enzyme activities while elevating the hepatic CPT and $\beta$-oxidation activity in the apo $E^{-/-}$mice.

\section{Conclusions}

In conclusion, this study provides evidence that low trans structured fat from corn oil reduces hepatic lipid accumulation via inhibition of lipogenesis while elevating fatty acid oxidation in apo $E^{-/-}$mice, a model for atherosclerosis. The differential effects of LC observed on the plasma and liver lipid profile seem to be partly due to the fatty acid composition of LC compared to CS, as LC is high in SFA, MUFA and PUFA content. High SFA in LC may explain the unfavorable effect of LC on plasma triglyceride concentration. We suggest that LC exerts both an anti-atherosclerotic and proatherosclerotic effect on plasma and liver lipid metabolism in an atherogenic susceptible animal model. However, further studies are required to verify differential the effects of specific fatty acid composition in low trans fats, on lipid metabolism, to justify recommendations to use low trans fats such as LC in food processing.

\section{Acknowledgements}

This work was supported by a grant from the Korea Science and Engineering Foundation, Ministry of Science and Technology (R01-2006-000-10567-0), Bio-Food Research Project, Kyungpook National University research fund 2007 and the SRC Program through the National Research Foundation of Korea (NRF) funded by the Ministry of Education, Science and Technology (20100001886), Republic of Korea. We thank Dr. Robin McGrgor, a member of the center for food and nutritional genomics, for critical reading of this manuscript.

\section{Author details}

'Department of Food Science and Nutrition, Kyungpook National University, Daegu, South Korea. ${ }^{2}$ Food and Nutritional Genomics Research Center, Kyungpook National University, Daegu, South Korea. ${ }^{3}$ Department of Food Science and Technology, Chungnam National University, Daejeon. ${ }^{4}$ Food R\&D, CJ Cheiljedang Corp., Seoul, South Korea.

\section{Authors' contributions}

CYY, KEY, KHJ, JSM, LKT and CMS participated in the design of the study, sample collection, analysis, statistical analysis, and writing of this paper. All authors read and approved the final manuscript.

\section{Competing interests}

The authors declare that they have no competing interests.

Received: 23 December 2010 Accepted: 20 January 2011

Published: 20 January 2011

\section{References}

1. Imaizumi M, Takeda M, Fushiki T: Effects of oil intake in the conditioned place preference test in mice. Brain Res 2000, 870:150-6.

2. Takeda M, Sawano S, Imaizumi M, Fushiki T: Preference for corn oil in olfactory-blocked mice in the conditioned place preference test and the two-bottle choice test. Life Sci 2001, 69:847-54.

3. Kuller LH: Nutrition, lipids, and cardiovascular disease. Nutr Rev 2006, 64: S15-26.

4. González C, Resa JM, Concha RG, Goenaga JM: Enthalpies of mixing and heat capacities of mixtures containing acetates and ketones with corn oil at $25^{\circ} \mathrm{C}$. J Food Eng 2007, 79:1104-9.

5. Kaku S, Ohkura K, Yunoki S, Nonaka M, Tachibana H, Sugano M, Yamada K: Dietary gamma-linolenic acid dose-dependently modifies fatty acid composition and immune parameters in rats. Prostaglandins Leukot Essent Fatty Acids 2001, 65:205-10.

6. Samman S: Dietary trans fatty acids and coronary heart disease. Food Australia 1995, 47:S10-3.

7. Khosla P, Hayes K: Dietary trans-monounsatyrated fatty acids negatively impact plasma lipids in humans: critical review of the evidence. J Am Coll Nutr 1996, 15:25-39.

8. Ascherio A, Willett WC: Health effects of trans fatty acids. Am J Clin Nutr 1997, 66:10065-10S.

9. Nestel P, Noakes M, Belling B, McArthur R, Clifton P, Janus E, Abbey M: Plasma lipoprotein lipid and $\mathrm{Lp}$ [a] changes with substitution of elaidic acid for oleic acid in the diet. I Lipid Res 1992, 33:1029-36.

10. Wood R, Kubena K, O'Brien B, Tseng S, Martin G: Effect of butter, monoand polyunsaturated fatty acid-enriched butter, trans fatty acid margarine and zero trans fatty acid margarine on serum lipids and lipoproteins in healthy men. $J$ Lipid Rrs 1993, 34:1-11.

11. Lichtenstein AH, Ausman LM, Carrasco W, Ordovas JM, Schaefer EJ: Hydrogenation impairs the hypolipidemic effect of corn oil in humans. Arterioscler Thromb 1993, 13:154-61. 
12. Seppanen-Laakso T, Vanhanen $H$, Laakso I, Kohtamaki H, Viikari J: Replacement of margarine on bread by rapeseed and olive oils: effects on plasma fatty acid composition and serum cholesterol. Ann Nutr Metab 1993, 37:161-74.

13. Hayes KC: Dietary fatty acids, cholesterol, and the lipoprotein profile. $\mathrm{Br} J$ Nutr 2000, 84:397-9.

14. Mensink RP, Zock PL, Kester AD, Katan MB: Effects of dietary fatty acids and carbohydrates on the ratio of serum total to $\mathrm{HDL}$ cholesterol and on serum lipids and apolipoproteins: a meta-analysis of 60 controlled trials. Am J Clin Nutr 2003, 77:1146-55.

15. Folch J, Lees M, Sloan-Stanley GH: A simple method for the isolation and purification of total lipids from animal tissues. J Biol chem 1957, 226:497-509.

16. Bradford MM: A rapid and sensitive method for the quantitation of microgram quantities of protein utilizing the principle of protein-dye binding. Anal Biochem 1976, 72:248-54.

17. Pitkanen E, Pitkanen O, Uotila L: Enzymatic determination of unbound dmannose in serum. Eur J Clin Chem Clin Biochem 1997, 35:761-6.

18. Ochoa S: Malic enzyme: malic enzymes from pigeon and wheat germ. In Methods in Enzymology. Volume 1. Edited by: Colowick SP, Kaplan NO. Academic Press, New York, NY; 1995:323-6.

19. Lazarow PB: Assay of peroxisomal $\beta$-oxidation of fatty acids. Methods Enzymol 1981, 72:315-9.

20. Markwell MAK, McGroarty EJ, Bieber LL, Tolbert NE: The subcellular distribution of carnitine acyltransferases in mammalian liver and kidney. J Biol Chem 1973, 248:3426-32.

21. Shapiro DJ, Nordstrom JL, Mitschelen JJ, Rodwell WW, Schimke RT: Micro assay for 3-hydroxy-3-methylglutaryl-CoA reductase in rat liver and in Lcell fibroblasts. Biochim Biophys Acta 1974, 370:369-77.

22. Erickson SK, Shrewsbury MA, Brooks C, Meyer DJ: Rat liver acyl-coenzyme A:cholesterol acyltransferase: its regulation in vivo and some of its properties in vitro. J Lipid Res 1980, 21:930-41.

23. Mensunk RP, Zock PL, Kester ADM, Katan MB: Effects of dietary fatty acids and carbohydrates on the ration of serum total to HDL cholesterol and on 60 controlled trials. Am J Clin Nutr 2003, 77:1146-55.

24. Stender S, Dyerber J: Influence of trans fatty acids on health. Nutr Metab 2004, 48:61-6.

25. Mathan NR, Welty FK, Barret HR, Harusz C, Dolnikowski GG, Parks JS, Eckel $\mathrm{RH}$, Schaefer $\mathrm{EJ}$, Lichtenstein $\mathrm{AH}$ : Dietary hydrogenated fat increases high-density lipoprotein apoA-I catabolism and decreases low-density lipoprotein apoB-100 catabolism in hypercholesterolemic women. Arterioscler Thromb Vasc Biol 2004, 24:1092-7.

26. Ascherio A, Katan MB, Zock PL, Stampfer MJ, Willett WC: Trans fatty acids and coronary heart disease. N Engl J Med 1999, 340:1994-8.

27. Walldius G, Jungner I, Holme I, Aastveit AH, Kolar W, Steiner E: High apolipoprotein B, low apolipoprotein A-I, and improvement in the prediction of fatal myocardial infarction (AMORIS study): a prospective study. Lancet 2001, 358:2026-33.

28. Phillips MC, Gillotte KL, Haynes MP, Johnson WJ, Lund-Katz S, Rothblat GH: Mechanisms of high density lipoprotein-mediated efflux of cholesterol from cell plasma membranes. Atherosclerosis 1998, 137:S13-7.

29. Betteridge DJ, Morrell JM: Clinicians Guide to Lipids and Coronary Heart Disease. London; 1999

30. Genest J Jr: The measurement of apolipoprotein B should replace the conventional lipid profile in screening for cardiovascular risk. I beg to differ. Can J Cardiol 1992, 8:138-40.

31. Koga T, Yamato T, Ikeda I, Sugano M: Effects of randomization of partially hydrogenated corn oil on fatty acid and cholesterol absorption, and tissue lipid levels in rats. Lipids 1995, 30:935-40.

32. Cho YY, Kwon EY, Kim HJ, Park YB, Lee KT, Park T, Choi MS: Low trans structured fat from flaxseed oil improves plasma and hepatic lipid metabolism in apo E(-/-) mice. Food Chem Toxicol 2009, 47:1550-5.

33. Grundy S, Denke M: Dietary influences on serum lipids and lipoproteins. J Lipid Res 1990, 31:1149-72.

34. Mensink RP: Effects of the individual saturated fatty acids on serum lipids and lipoprotein concentrations. Am J Clin Nutr 1993, 57:711S-4S.

35. Mensink RP, Zock PL, Kester AD, Katan MB: Effects of dietary fatty acids and carbohydrates on the ratio of serum total to $\mathrm{HDL}$ cholesterol and on serum lipids and apolipoproteins: A meta-analysis of 60 controlled trials. Am J Clin Nutr 2003, 77:1146-55
36. El-Sohemy A, Kendall CW, Rao AV, Archer MC, Bruce WR: Dietary cholesterol inhibits the development of aberrant crypt foci in the colon. Nutr Cancer 1996, 25:111-7.

37. El-Sohemy A, Bruce WR, Archer MC: Inhibition of rat mammary tumorigenesis by dietary cholesterol. Carcinogenesis 1996, 17:159-62.

38. Yao Z, McLeod RS: Synthesis and secretion of hepatic apolipoprotein B-containing lipoproteins. Biochim Biophys Acta 1994, 1212:152-66.

39. Sniderman AD, Cianflone K: Substrate delivery as a determinant of hepatic apoB secretion. Arterioscler Thromb 1993, 13:629-36.

40. Thompson GR, Naoumova RP, Watts GF: Role of cholesterol in regulating apolipoprotein B secretion by the liver. J Lipid Res 1996, 37:439-47.

41. Chang CC, Sakashita N, Ornvold K, Lee O, Chang ET, Dong R, Lin S, Lee CY, Strom SC, Kashyap R, Fung JJ, Farese RV Jr, Patoiseau JF, Delhon A, Chang TY: Immunological quantitation and localization of ACAT-1 and ACAT-2 in human liver and small intestine. J Biol Chem 2000, 275:28083-92.

42. Brown MS, Goldstein JL: Lipoprotein metabolism in the macrophage: implications for cholesterol deposition in atherosclerosis. Annu Rev Biochem 1983, 52:223-61.

43. Memon RA, Grunfeld C, Moser AH, Feingold KR: Fatty acid synthesis in obese insulin resistant diabetic mice. Horm Metab Res 1994, 26:85-7.

doi:10.1186/1476-511X-10-15

Cite this article as: Cho et al:: Differential effect of corn oil-based low trans structured fat on the plasma and hepatic lipid profile in an atherogenic mouse model: comparison to hydrogenated trans fat. Lipids in Health and Disease 2011 10:15.

\section{Submit your next manuscript to BioMed Central and take full advantage of:}

- Convenient online submission

- Thorough peer review

- No space constraints or color figure charges

- Immediate publication on acceptance

- Inclusion in PubMed, CAS, Scopus and Google Scholar

- Research which is freely available for redistribution

Submit your manuscript at www.biomedcentral.com/submit
C) Biomed Central 